\title{
PERCEPTIONS OF BENEFICIARY FAMILIES OF INTEGRATED SOCIAL PROTECTION SERVICES IN POVERTY ALLEVIATION THROUGH CENTER OF SOCIAL WELFARE (PUSKESOS) (CASE STUDY OF SABILULUNGAN INTEGRATED SERVICE AND REFERRAL SYSTEM (SLRT) PROGRAM IN BANDUNG REGENCY)
}

\author{
Denti Kardeti \\ Politeknik Kesejahteraan Sosial (Poltekesos) Bandung, dentikardeti@gmail.com \\ Budhi Gunawan \\ Departement of Antrophology, Faculty of Social and Politic Sciences, Universitas \\ Padjadjaran, Indonesia \\ Binahayati Rusyidi \\ Department of Social Welfare, Faculty of Social and Politic Sciences, Universitas \\ Padjadjaran, Indonesia \\ Mira Azzasyofia \\ Politeknik Kesejahteraan Sosial (Poltekesos) Bandung, miraazzasyofia@gmail.com
}

\section{Abstract}

This study shows the factors that influence integrated social protection services from the perspective of the beneficiaries at integrated and referral system (SLRT) in Bandung Regency. Respondents of this study were 284 beneficiaries of integrated social protection services. This research uses quantitative research methods. The results of this study indicate that center of social welfare (Puskesos) in Bandung Regency have implemented integrated social protection. Beneficiary families also considered that officers were able to provide new information as an effort to solve problems. The existence of Puskesos provides convenience and time effectiveness for beneficiary families due to the one-stop service. This one-stop service proves that there is coordination and communication between related agencies. This collaboration is supported by the commitment of various parties, such as stakeholders in Bandung Regency from local stakeholders at the village level to Puskesos officials themselves. However, in infrastructure aspect, some beneficiary families felt they were not satisfied with infrastructure, such as the comfort when they were about to submit a complaint.

Keywords: social protection services, integrated services, poverty 


\section{INTRODUCTION}

Social welfare is an order of life in which the social problems are controllable, social needs are available and opportunities for advancement socially are open (Midgley, 1995; quoted by Soelaiman, 2017). To realize the purpose of social welfare, social welfare or social services efforts are needed, through a program or activity that is designed to deal with the solving of social problems, meet the needs of individuals, families, groups in the community and the society to improve their standard of living (Adi, 2013). Social services can be developed by the government, non- government organizations, and private sectors.

The Government of Indonesia and almost all of the countries continue to improve social welfare through improving the quality of life of the people, one of the way is to implement the Millennium Development Goals (MDGs). Implementation of the MDGs scheduled only until the year 2015. As the agenda of the sequel, the United Nations has set the agenda of development which is called the Sustainable Development Goals (SDGs). The SDGs concept is formed as a new development framework that accommodates changes that have occurred after the MDGs. Liu, Yu, and Wang (2015) explained that with the SDGS, poverty can be reduced and the way to overcome it is through sustainable programs. SDGs is a frame work which is schedule to achive until the year 2030. One of the main attention in the SDGs is poverty allevation through comperhensif social protection programs ( Wahyuningsih , 2017).

One of the biggest challenges in giving social protection is the fragmented system of the provision of the services (Bunger, 2011).
Fragmented service, may cause confusion to clients due to existing systems and problematic relationships between services. Miguel Niño- Zarazua (2012) adds that the fragmented services are a trouble to the poverty alleviation program. With this type of service, the achievement of the program cannot reach to the maximum level and it will be hard to solve deep social problems.

Based on Department of Social Affairs in Bandung Regency, poverty rate in Bandung Regency is fluctuating. Through exposure to these, the numbers of poverty declined from the year 2011 until the year 2014. In the year 2015 the numbers of poverty experienced a rise that is sufficiently high with 281.040. Instability of poverty rate are due to the poverty alleviation program and the handling of social problems still on sectoral basis. The lack of synergy between poverty alleviation programs makes the handling of the poor based on the interests of some parties. This is line with statement that stated by Suharto (2009), He said that social protection programs in developing countries which are partial, residual, and fragmented. Implementation of social protection program that still partial may cause problems, especially problems in coordination and programs implementation become ineffective. Sumardi (2017) adds that lack of coordination in poverty data collection become one of the biggest problems in the implementation of social protection program in Indonesia. The differences about poverty criteria in central and region government. Furthermore, National Development Planning Agency (Bappenas) stated that in the future, Indonesia needs integrated social protection system. An integrated social 
protection system could give comprehensive intervention and could maximize the coordination for poverty alleviation program.

Handling of poverty which is the problem of multidimensional required treatment from various perspectives and continuing through mentoring. Law No. 11 Year 2009 has mandated that the implementation of wellbeing social are done by the government both central and regional as well as the community in addition to be focused and sustainable, also should be integrated, in addition to that based on Law No. 13 Year 2011 About the handling of the Poor has been stated that the handling of the poor is an effort that is focused, integrated and sustainable that do Government, the Government of the Region, and or community.

Based on the consideration, then in year 2015 Bandung Regency organized System Services Reference Integrated (SLRT). SLRT ensure the poor and not able to gain access to social protection and social care programs, in addition to the existence of Program Integration -related needs of food, clothing, housing, health, education, employment, and / or services of social violence against women and children as well as the problems of others. SLRT function in the integration of information data and services, the identification of the complaints referral and handling of complaints , registration of membership needs program and updating the list penerim benefits are dynamic.

Seeing the problems of poverty that it has implemented the service or business venture welfare socially integrated are applied through Puskesos as arms length from SLRT that has impact directly to the family of the recipient benefits . implementation services can be seen from the impact of that received by the family of the recipient service as target major changes. The impact that can be worth a positive or negative that can be seen from the perception of family recipients benefit in assessing the services that have been received from Puskesos. Perception of family beneficiaries benefits that is one of the aspects to be able to determine the implementation of elements of the integration of the social protection programs are effective .

Welfare state focuses on the improvement of well-being in which the state provides services that comprehensively to its citizens. Spiker (1995: 82) states that the state welfare is an idea in which the state provides a service that is comprehensive to the public in order to be able to enjoy life standard . With other words, the state is defined as a safety and patron of the group is weak. In the line of big state welfare is very closely related to the social policy which consists of the strategies and efforts of the government in improving the welfare of its citizens, especially through the social protection, which includes social security and social assistance.

Social protection is an important element in a social policy strategy to reduce poverty . Barrientos (2010), stated social protection associated with the various institutions of society, norms, and programs that aim to protect the workers, and home stair them of an incident that threatens the standard of living basis. Then in the 1990s, social protection programs experience the transformation is important, especially in the context of the countries were developing . Social protection in the country growing 
increasingly rising to explain the framework of employment policies to tackle poverty and insecurity, in the face of the crisis economy, adjusting the structure, and globalization. Under the terms, social protection can be defined as the act of the public, which is taken in responding to the level of vulnerability, risk, and shortcomings which are considered not to be accepted as socially in government or community specific (Conway et al., 2000).

Social protection program by providing serve and social services to help improve the quality of life of society. Providing services that qualified to the public is a matter important that affect the productivity of program administration. Chambers added, programs and policies are made for the social protection, should have more than one benefit and have some purpose. Policy social that gave birth to the services of social not be seen as something that provides a benefit single.

Social protection that is fragmented, partial and not coordinated with the well can provide impact negatively on the giver and the recipient of the benefits of its services. Holmes (2010) explained that the actors are involved in the social protection in Indonesia, still has not had a coordination that is strong. For example, the recipient of service often become confused because the need to visit a variety of services social are different and sometimes information that is obtained is repeated. In fact, there are cases where the services are given are not in accordance with the needs of the client .

Departing from the terms of the, emerging paradigm of new , namely the integrated social protection system, where the services were supplied was in the roof, so it is expected will be more effective. Munday
(2007) explained about the elements of integrated social protection consists on an integrated vertical and integrated horizontal. Integrated vertical comprises top -level macro that relationship and coordination of policies between levels of government ( national, regional, local as well as the level of micro ie the relationship and coordination between the client with the community and providers of services of local / local. Integrated horizontal that is uniting the various services the public to mutually work together and achieve the goal the same. According to Ragan (2003) there are dimensions other as a factor supporting that affect the implementation of the services integrated are factors operating, factors admimistratif, and factors critical . factors operations, in which there is a union of location services or collocation, integration of intake and assessment, consolidation function staff executive, and consolidated management of the case. Factors administratively by Ragan consists of a consolidation of the structure of government , the integration of the flow of funds, and fixes errors that arise, collaboration to provide services additional, integrating over many services, the integration of the system informa si. The next factor that influences the implementation of integrated services is a crucial factor . According to Ragan, which is included in the factors crucial is leadership, development staff, the purpose of which is clear and the same, focusing on the community, the measurement of performance, the relationship personal, source power, their team, time, patience, and work hard. Factors crucial this is a factor 
that must be held in each manager and staff executive .

Social services into its center, the assisted areas of others such as health, education, energy work, and law. Chambers (2000) says that the program that was formed to deal with the problem of poverty should have more than one benefit . It is because poverty is a problem that is multidimensional, then out of it , must be considered and addressed every dimension that affects the occurrence of poverty. According to Chambers (2000) to deal with the problem that, various aspects must be addressed, ranging from assistance to the people of the poor are morally and materially, up to the level of policy . In Indonesia, one of the integrated programs to address poor families is the Integrated Referral Service System (SLRT) and Puskesos as an extension of SLRT I in every village and sub- district. Beneficiary families as the target changes to a population that is capable rated appropriate for gives ratings to service Puskesos as the recipient of the service is direct. According to Leavitt (1978) perception in a narrow sense is vision, the way a person sees something, while in a broad sense it is a view or understanding , namely the way a person perceives or interprets something. Opinions others raised by Hammer and Organ ( 1975 ) which defines perception as a process in which a person organizing in mind, interpreting, experience and cultivate a sign or any thing that is happening in the environment . In part this is described about perception of beneficiary families to Puskesos services based on the results and findings in the field.

\section{METHOD}

This study uses a quantitative method used to determine the perceptions of beneficiary families of Puskesos services in Bandung Regency. The data collection technique used in this study is a questionnaire. The questionnaire was conducted on the beneficiaries of each Puskesos in Bandung Regency. Bandung Regency has 280 Puskesos in 31 sub-districts, 270 villages and 10 urban villages. Of the 280 health centers that have run integrated services and are said to be successful, there are 74 Puskesos. This study uses a Likert scale measuring instrument to measure a person's perception of a phenomenon. The questionnaire instrument is the result of compilation carried out by the researcher. The answer to each statement item in the questionnaire that uses the Likert scale has a gradient from very positive to very negative which consists of alternative answers to strongly agree (SS), agree (S), disagree (KS), disagree (TS) and strongly disagree ( STS). The number of beneficiary families who were respondents in this study was measured based on the proportion of each category of Puskesos. The data that the researchers managed to collect were in the very good category a total of 4 Puskesos with 96 beneficiary families, a good category of 30 Puskesos with 93 beneficiary families and a moderate category of 36 Puskesos with 95 beneficiary families.

The validity test used in this study is face validity. Advance validity which relates to the expert's assessment of a measuring instrument. Efforts are made to test the validity of measuring instruments by consulting the appropriateness of measuring instruments to experts before the instruments are used for data collection. Researchers 
consulted measuring instruments to experts. The instrument is said to be valid if the expert has stated that the measuring instrument is suitable for use. Based on the results of the calculations that the researcher has done, through this table it can be found that the reliability of the questionnaire is 0.856 and it means that the questionnaire is reliable in every detail of the statement items. Processing and data analysis carried out in this study using a statistical method program using IBM SPSS 22.

\section{RESULT AND DISCUSSION}

Bandung Regency is one of 18 districts in West Java Province, which has an area of $1,762.40 \mathrm{Km} 2$ or $4.74 \%$ of the area of West Java or $1.37 \%$ of the area of Java Island. In addition, Bandung Regency is located between 60.41 'to 70.19' south latitude (LS) and between 1070.22 'to 1080.5' east longitude (BT). Bandung Regency is a buffer area for the capital of West Java Province with the northern boundary surrounding the capital area. Some districts with the distance of more than $30 \mathrm{~km}$ to the capital of Bandung Regency include: Nagreg, Kertasari, Pacet, Cikancung, Cicalengka, Rancaekek, Ibun, Solokan Jeruk, Paseh, Cileunyi and Pangalengan Districts. Meanwhile, subdistricts with the distance of less than $10 \mathrm{~km}$ from the capital city of Bandung Regency are Margaasih, Margahayu, Banjaran, Katapang, Cangkuang and Kutawaringin Districts. The area with the highest poverty rate in Bandung Regency is Pangalengan District. Geographically, the Pangalengan area has remote access and often experiences blind spots or areas without a signal. Most of the area in Pangalengan consists of plantations owned by outsiders so that the majority of the local community work as tea pickers who are paid very low wages. Most of the people in Bandung Regency take the highest education up to Senior High School (SMA) as many as 472,320 people. Only 177,607 people continue to the Diploma level education. The unemployment rate is also high, at 64,673 people.

Respondents were Beneficiary Families (beneficiary families) in 2019 which were determined by random sampling technique with proportional characteristics of the very good, good and moderate Puskesos. Information obtained through distributing questionnaires. The number of respondents in the very good category of Puskesos is 96 beneficiary families, 93 beneficiary families in good category and 95 beneficiary families of medium category Puskesos are spread across 70 Puskesos in 29 Districts in Bandung Regency. Most of the respondents were in the range of 20-45 years. Most of the respondents have attained the education level of SD / MI/ equivalent, so that the majority of respondents' main job is as casual daily laborers or not working. Some of the beneficiary families live in their own houses with 1-14 members in one house consisting of 1 - 2 heads of families. Beneficiary families of Puskesos service have several other dependents. The majority of school age children and toddlers are at most 5 children, while the elderly (elderly), persons with disabilities and pregnant women mostly consist of 1-2 people in one house. Beneficiaries said that most of the services provided had met their expectations. This can be seen in the tabel 1 . 
Tabel 1 Perceptions of Beneficiary Families of Integrated Social Protection Services in Poverty Alleviation Central of Social Welfare (Puskesos)

\begin{tabular}{|c|c|c|c|c|c|c|c|c|}
\hline No & Statement & $\begin{array}{l}\text { Strongly } \\
\text { Disagree }\end{array}$ & Disagree & $\begin{array}{c}\text { Little } \\
\text { Disagree }\end{array}$ & Agree & $\begin{array}{l}\text { Strongly } \\
\text { Agree }\end{array}$ & total & Skor \\
\hline 1. & I know the excistence of Puskesos & $\begin{array}{c}0 \\
0,00 \%\end{array}$ & $\begin{array}{c}3 \\
1,06 \%\end{array}$ & $\begin{array}{c}6 \\
2,11 \%\end{array}$ & $\begin{array}{c}150 \\
52,82 \%\end{array}$ & $\begin{array}{c}1125 \\
44,01 \%\end{array}$ & $\begin{array}{c}284 \\
100 \%\end{array}$ & $\begin{array}{c}1.249 \\
87,96 \%\end{array}$ \\
\hline 2. & I know Puskesos official & $\begin{array}{c}0 \\
0,00 \% \\
\end{array}$ & $\begin{array}{c}3 \\
1,06 \%\end{array}$ & $\begin{array}{c}5 \\
1,76 \%\end{array}$ & $\begin{array}{c}156 \\
54,93 \% \\
\end{array}$ & $\begin{array}{c}120 \\
42,25 \% \\
\end{array}$ & $\begin{array}{c}284 \\
100 \%\end{array}$ & $\begin{array}{c}1.245 \\
87,68 \%\end{array}$ \\
\hline 3. & I know services that provides by Puskesos & $\begin{array}{c}0 \\
0,00 \%\end{array}$ & $\begin{array}{c}4 \\
1,41 \%\end{array}$ & $\begin{array}{c}12 \\
4,23 \%\end{array}$ & $\begin{array}{c}154 \\
54,23 \%\end{array}$ & $\begin{array}{c}114 \\
40,14 \%\end{array}$ & $\begin{array}{c}284 \\
100 \%\end{array}$ & $\begin{array}{c}1.230 \\
86,62 \%\end{array}$ \\
\hline 4. & Location of Puskesos easy to find & $\begin{array}{c}0 \\
0.00 \% \\
\end{array}$ & $\begin{array}{c}5 \\
1,41 \% \\
\end{array}$ & $\begin{array}{c}7 \\
4,23 \% \\
\end{array}$ & $\begin{array}{c}149 \\
52,46 \%\end{array}$ & $\begin{array}{c}123 \\
43,31 \% \\
\end{array}$ & $\begin{array}{c}284 \\
100 \%\end{array}$ & $\begin{array}{c}1.242 \\
87,46 \%\end{array}$ \\
\hline 5. & Requirements of Puskesos easy to fullfil & $\begin{array}{c}0 \\
0,00 \% \\
\end{array}$ & $\begin{array}{c}2 \\
0,70 \%\end{array}$ & $\begin{array}{c}6 \\
2,11 \% \\
\end{array}$ & $\begin{array}{c}166 \\
58,45 \%\end{array}$ & $\begin{array}{c}110 \\
38,73 \% \\
\end{array}$ & $\begin{array}{c}284 \\
100 \%\end{array}$ & $\begin{array}{c}1.236 \\
87,04 \% \\
\end{array}$ \\
\hline 6. & $\begin{array}{l}\text { Education, health, and social economy services located } \\
\text { in the same building }\end{array}$ & $\begin{array}{c}0 \\
0,00 \%\end{array}$ & $\begin{array}{c}12 \\
4,23 \%\end{array}$ & $\begin{array}{c}14 \\
4,93 \%\end{array}$ & $\begin{array}{c}154 \\
54,23 \%\end{array}$ & $\begin{array}{c}104 \\
36,62 \%\end{array}$ & $\begin{array}{c}284 \\
100 \%\end{array}$ & $\begin{array}{c}1.202 \\
84,65 \%\end{array}$ \\
\hline 7. & Complaints services procedure by Puskesos is good & $\begin{array}{c}0 \\
0,00 \% \\
\end{array}$ & $\begin{array}{c}4 \\
1,41 \% \\
\end{array}$ & $\begin{array}{c}10 \\
3,52 \% \\
\end{array}$ & $\begin{array}{c}170 \\
59,85 \%\end{array}$ & $\begin{array}{c}100 \\
35,21 \%\end{array}$ & $\begin{array}{c}284 \\
100 \%\end{array}$ & $\begin{array}{c}1.218 \\
85,77 \%\end{array}$ \\
\hline 8. & Service time is according to the schedule & $\begin{array}{c}0 \\
0,00 \%\end{array}$ & $\begin{array}{c}0 \\
0,00 \%\end{array}$ & $\begin{array}{c}12 \\
4,23 \%\end{array}$ & $\begin{array}{c}171 \\
6-, 21 \%\end{array}$ & $\begin{array}{c}101 \\
35,56 \%\end{array}$ & $\begin{array}{c}284 \\
100 \%\end{array}$ & $\begin{array}{c}1.225 \\
86,27 \%\end{array}$ \\
\hline 9. & Puskesos services are free & $\begin{array}{c}0 \\
0,00 \%\end{array}$ & $\begin{array}{c}0 \\
0,00 \%\end{array}$ & $\begin{array}{c}2 \\
0,70 \%\end{array}$ & $\begin{array}{c}129 \\
45,42 \%\end{array}$ & $\begin{array}{c}153 \\
53,87\end{array}$ & $\begin{array}{c}284 \\
100 \%\end{array}$ & $\begin{array}{c}1.287 \\
90,83 \\
\%\end{array}$ \\
\hline 10. & $\begin{array}{l}\text { Puskesos official had the ability to providing the } \\
\text { information about Puskesos services. }\end{array}$ & $\begin{array}{c}0 \\
0,00 \%\end{array}$ & $\begin{array}{c}0 \\
0,00 \%\end{array}$ & $\begin{array}{c}4 \\
1,41 \%\end{array}$ & $\begin{array}{c}162 \\
57,04 \%\end{array}$ & $\begin{array}{c}118 \\
41,55 \%\end{array}$ & $\begin{array}{c}284 \\
100 \%\end{array}$ & $\begin{array}{c}1.250 \\
88,03 \%\end{array}$ \\
\hline 11. & $\begin{array}{l}\text { Puskesos official had the ability to providing the } \\
\text { information about Family Hope Program (PKH), Non- } \\
\text { Cash Food Assistance (BPNT) and Rumah Tidak Layak } \\
\text { Huni (RTLH) }\end{array}$ & $\begin{array}{c}0 \\
0,00 \%\end{array}$ & $\begin{array}{c}1 \\
0,35 \%\end{array}$ & $\begin{array}{l}10 \\
3,52 \%\end{array}$ & $\begin{array}{c}155 \\
54,58 \%\end{array}$ & $\begin{array}{c}118 \\
41,55 \%\end{array}$ & $\begin{array}{c}284 \\
100 \%\end{array}$ & $\begin{array}{c}1.242 \\
87,46 \%\end{array}$ \\
\hline 12. & $\begin{array}{l}\text { Puskesos official had the ability to providing the } \\
\text { information about Smart Indonesia Card (KIP) }\end{array}$ & $\begin{array}{c}0 \\
0,00 \%\end{array}$ & $\begin{array}{c}6 \\
2,11 \% \\
\end{array}$ & $\begin{array}{c}12 \\
4,23 \% \\
\end{array}$ & $\begin{array}{c}165 \\
58,10 \%\end{array}$ & $\begin{array}{c}101 \\
35,56 \%\end{array}$ & $\begin{array}{c}284 \\
100 \%\end{array}$ & $\begin{array}{c}1.213 \\
85,42 \%\end{array}$ \\
\hline
\end{tabular}


IJSW: Indonesian Journal of Social Work Vol.04 No.1, August, 2020

\begin{tabular}{|c|c|c|c|c|c|c|c|c|}
\hline 13. & $\begin{array}{l}\text { Puskesos official had the ability to providing the } \\
\text { information about the Social Security Provider Body for } \\
\text { Health (BPJS) and Healthy Indonesia Card (KIS) }\end{array}$ & $\begin{array}{c}0 \\
0,00 \%\end{array}$ & $\begin{array}{c}0 \\
0,00 \%\end{array}$ & $\begin{array}{c}2 \\
0,70 \%\end{array}$ & $\begin{array}{c}166 \\
58,45 \%\end{array}$ & $\begin{array}{c}116 \\
40,85 \%\end{array}$ & $\begin{array}{c}284 \\
100 \%\end{array}$ & $\begin{array}{c}1.250 \\
88,03 \%\end{array}$ \\
\hline 14. & $\begin{array}{l}\text { Puskesos official had the ability to write down my } \\
\text { complaints }\end{array}$ & $\begin{array}{c}0 \\
0,00 \%\end{array}$ & $\begin{array}{c}3 \\
1,06 \%\end{array}$ & $\begin{array}{c}5 \\
1,76 \%\end{array}$ & $\begin{array}{c}175 \\
61,62 \%\end{array}$ & $\begin{array}{c}101 \\
35,56 \%\end{array}$ & $\begin{array}{c}284 \\
100 \%\end{array}$ & $\begin{array}{l}1.226 \\
86,34 \%\end{array}$ \\
\hline 15. & Puskesos official are patient in listening to complaints & $\begin{array}{c}0 \\
0,00 \%\end{array}$ & $\begin{array}{c}0 \\
0,00 \%\end{array}$ & $\begin{array}{c}8 \\
2,82 \%\end{array}$ & $\begin{array}{c}162 \\
57,04 \%\end{array}$ & $\begin{array}{c}114 \\
40,14 \%\end{array}$ & $\begin{array}{c}284 \\
100 \%\end{array}$ & $\begin{array}{c}1.242 \\
87,46 \%\end{array}$ \\
\hline 16. & $\begin{array}{l}\text { Puskesos official are understanding in accepting } \\
\text { complaints }\end{array}$ & $\begin{array}{c}0 \\
0,00 \%\end{array}$ & $\begin{array}{c}0 \\
0,00 \%\end{array}$ & $\begin{array}{c}3 \\
1,06 \%\end{array}$ & $\begin{array}{c}169 \\
59,51 \%\end{array}$ & $\begin{array}{c}112 \\
38,44\end{array}$ & $\begin{array}{c}284 \\
100 \%\end{array}$ & $\begin{array}{c}1.245 \\
87,68 \%\end{array}$ \\
\hline 17. & $\begin{array}{l}\text { Puskesos official are responsive in responding to } \\
\text { complaints }\end{array}$ & $\begin{array}{c}0 \\
0,00 \%\end{array}$ & $\begin{array}{c}0 \\
0,00 \%\end{array}$ & $\begin{array}{c}5 \\
1,76 \%\end{array}$ & $\begin{array}{c}166 \\
58,45 \%\end{array}$ & $\begin{array}{c}113 \\
39,79\end{array}$ & $\begin{array}{c}284 \\
100 \%\end{array}$ & $\begin{array}{c}1.244 \\
87,61 \%\end{array}$ \\
\hline 18. & $\begin{array}{l}\text { The existence of Puskesos makes it easier to get various } \\
\text { services }\end{array}$ & $\begin{array}{c}0 \\
0,00 \%\end{array}$ & $\begin{array}{c}0 \\
0,00 \%\end{array}$ & $\begin{array}{c}6 \\
2,11 \% \\
\end{array}$ & $\begin{array}{c}148 \\
52,11 \%\end{array}$ & $\begin{array}{c}127 \\
44,72\end{array}$ & $\begin{array}{c}284 \\
100 \%\end{array}$ & $\begin{array}{c}1.263 \\
88,94 \% \\
\end{array}$ \\
\hline 19. & $\begin{array}{l}\text { The services provided by Puskesos in integrated manner } \\
\text { can solve the problem }\end{array}$ & $\begin{array}{c}0 \\
0,00 \%\end{array}$ & $\begin{array}{c}0 \\
0,00 \% \\
\end{array}$ & $\begin{array}{c}7 \\
2,46 \% \\
\end{array}$ & $\begin{array}{c}167 \\
58,80 \% \\
\end{array}$ & $\begin{array}{c}110 \\
38,73\end{array}$ & $\begin{array}{c}284 \\
100 \%\end{array}$ & $\begin{array}{c}1.239 \\
87,25 \% \\
\end{array}$ \\
\hline 20. & $\begin{array}{l}\text { The availability of facilities and infrastructure at the } \\
\text { Puskesos secretariat such as signboards, service } \\
\text { mechanism boards, waiting rooms, service rooms, work } \\
\text { equipment and complaint boxes. }\end{array}$ & $\begin{array}{c}0 \\
0,00 \%\end{array}$ & $\begin{array}{c}16 \\
5,63 \%\end{array}$ & $\begin{array}{c}68 \\
23,94 \%\end{array}$ & $\begin{array}{c}123 \\
43,31 \%\end{array}$ & $\begin{array}{c}77 \\
27,11\end{array}$ & $\begin{array}{c}284 \\
100 \%\end{array}$ & $\begin{array}{c}1.113 \\
78,38 \%\end{array}$ \\
\hline & & & & & & & Total & $\begin{array}{r}24.657 \\
86,82 \% \\
\end{array}$ \\
\hline
\end{tabular}

Source: research fundings 
Based on table 1, it can be concluded that most of the beneficiary families assessed that Puskesos services were good. The total score got 28,400 which is $86.82 \%$ of the ideal score of 28,400 . Here in the column score each statement item gets a good percentage, above $75 \%$ of the ideal score of each statement item, which is 1,420 . beneficiary families knows the existence of Puskesos so that it is easy to reach the location to get Puskesos services. Beneficiary Families (beneficiary families) can play an active role in submitting complaints. Through the existence of Puskesos, the problem solving in villages and sub-districts runs more effectively because it does not require outreach to all targets, but problems and target needs are accepted based on the submission of beneficiary families to Puskesos.

Puskesos officers are the spearhead of service, for that beneficiary families assesses that officers are able to accommodate complaints from the public and provide excellent service both competently and personally, namely patience, friendliness and agility. The high number of knowledge of these Puskesos officers means that the trust of beneficiary families is easy to build. The implementation of data verification and validation that requires personal information from beneficiary families is easy to provide because they already know and believe that the information data will not be misused and later through this data it will improve the services received by the beneficiary families concerned.

beneficiary families knows the services provided by Puskesos, so the integration of information and services will be faster with a reciprocal relationship between beneficiary families and officers. beneficiary families is able to identify, refer and reach complaint handling appropriately because they already know where the nearest source system is able to help. The participation of beneficiary families certainly makes it easier to register participation and identify program needs so that poverty alleviation through Puskesos can be effective.

The requirements in the registration stage are understandable and make it difficult for KPMs to obtain services at most KPMs have demographic legality which shows their domicile in the village or kelurahan so that they can quickly and easily get services. The administration of the population is an initial requirement to be able to submit complaints which later as a follow-up to the beneficiary families complaint, of course the beneficiary families completes additional requirements whose types and procedures have been informed by the officer. Most of the social welfare centers (Puskesos) at the village / kelurahan level have been implemented so that it is easy for service recipients to get various program information through one door and can take advantage of various programs according to their needs and problems through one roof quickly.

In its implementation, the Puskesos unit takes care of access to social referral services, explores sources of social welfare, facilitates the economic business of the poor and vulnerable to the poor, consisting of one of them is an officer in the socio-economic sector including special handling of child violence. Knowledge related to the socioeconomic field is obtained through experience in the field when direct assistance from the center will be disbursed. The socio- 
economic sector is the field that deals with programs that are physically overlooked because most of the forms can be seen such as funds, basic necessities and assistance to rehabilitate uninhabitable houses. Officers are considered qualified in providing various fields of service, namely education through the Smart Indonesia program and in the health sector such as BPJS, KIS and PBI

In its implementation, Puskesos utilizes integrated information technology. Not only people and sources of funds, facilities and infrastructure must support the implementation of Puskesos. Excellent service, of course, must be supported by the facilities and infrastructure at each Puskesos. The difference in the formation time of Puskesos provides differences in development so that the categorization of Puskesos appears to be very good, good and moderate. The categorization refers to the extent to which the readiness of service is available from various aspects, one of which is through means and means. Most of the Puskesos are in the good category, namely with adequate facilities and infrastructure such as SK, secretariat, administrative completeness, uniforms, handling complaints, active management, conducting verval, cross-sector cooperation, mastering PMKS and PSKS and mastering IT. There are also Puskesos with infrastructure that are deemed inadequate because they are newly formed and only have a SK. Puskesos with the very good category have complete facilities and infrastructure, administration, qualified human resources and the advantages of having products from the jointly guided business group.

\section{CONCLUSION}

Based on the research findings, it can be concluded that the perception of beneficiary families towards Puskesos services is positive. According to Robins (2002: 14) that positive perception is an individual's assessment of an object or information in accordance with what is expected from the object or existing rules. This provides information that most of the beneficiary families services provided by Puskesos are good, based on the scoring results of filling out the questionnaire. This perception is built by individuals based on their experiences as well as the experience of submitting complaints from beneficiary families to Puskesos which are responded quickly by Puskesos officers who are considered to be able to provide satisfaction in the application of problem-solving plans for each beneficiary families, besides beneficiary families assesses that officers are able to provide new information in upaa problem solving. Based on the table, it can be seen that the statement with the lowest score is related to infrastructure, in this case some beneficiary families assessed that they were not satisfied with infrastructure such as comfort when they were about to submit complaints. This situation is related to the Puskesos category itself which is still in the developing stage, especially the middle category which still does not have its own secretariat building.

\section{REFERENCES}

Barrientos, Armando.2010. Social Protection and Poverty. Social Policy and Development Programme Paper Number No. 42. E-paper. United 
Nations Research Institute for Social Development.

Bunger, A. C. 2010. Defining service coordination: A social work perspective. Journal of social service research, 36, 5, 385-401.

Chambers, Donald E. 2000. Social Policy and Social Programs. US: Allyn and Bacon.

Conway, Tim dan Mick Foster. 2001. Social Protection Concepts and Approaches: Implications for Policy and Practice in International Development. London: Overseas Development Institutes.

Creswell, J. W., V. L. Plano Clark, M. Gutmann, and W. Hanson. 2003. Advanced mixed methods research designs. In Handbook On Mixed Methods In The Behavioral And Social Sciences, ed. A. Tashakkori and C. Teddlie, 209-40. Thousand Oaks, CA: Sage.

Creswell, J.W. 2013. Research Design: Pendekatan Kualitatif, Kuantitatif, dan Mixed. Yogyakarta: Pustaka Pelajar.

Endro Winarno, Kissumi Diyanati dan Etty Padmiati. 2013. Pengembangan Model Pelayanan Terpadu dan Gerakan Masyarakat Peduli Kabupaten/ Kota Sejahtera (PANDU GEMPITA) di Kabupaten Sragen Provinsi Jawa Tengah. Penelitian, Bandung: Sekolah Tinggi Kesejahteraan Sosial.

Fahrudin, Adi 2012. Pengantar Kesejahteraan Sosial. Bandung : Refika Aditama.

Hammer, W.C dan Organ, D.W . 1975. Organizational Behavior: An Applied Pschycological Approach. Dallas : Busines Inc.
Holmes, Rebecca., Febriany, Vita., Yumna, A. \& Syukri, M.2010. The Role of Social Protection in Tackling Food Insecurity and Under-Nutrition in Indonesia: A Gendered Approach. Overseas Development Institute and the SMERU Research Institute, UK.

Ivankova, N. V., Creswell, J. W., \& Stick, S. L. (2006). Using Mixed-Methods Sequential Explanatory Design: From Theory To Practice. Field Methods, 18(1), 3-20.

Leavitt,Harold J. 1978. Managerial Psychology on Introduction to Individual, Pairs and Groups in Organization. Chicago : The University of Chicago Press.

Liu, Qian-Qian, Man Yu, Xiao-Lin Wang. 2015. Poverty Reduction Within The Framework of SDGs and Post-2015 Development Agenda, Advances in Climate Change Research, 6, 67-73. DOI: $\quad$ https://doi.org/10.1016/j.accre .2015 .09 .004

Miles, M.B. and Huberman, A.M. 1994. Qualitative Data Analisys. Thousand Oaks, London, New Delhi: Sage Publications.

Morais de Sá e Silva, Michelle. 2008. Opportunity NYC: A performance based conditional cash transfer programme. A quantitative analysis, Working Paper, International Poverty Centre, No. 49.

Munday, B. 2003. European Social Services: A Map Of Characteristics And Trends. Strasbourg, France: Council of Europe.

Niño-Zarazúa, Miguel, Barrientos, A., Hickey, S., \& Hulme, D. 2012. Social 
Protection in Sub-Saharan Africa:

Getting the politics right. World Development, 40, 1, 163-176.

Pedoman Umum Pelaksanaan Sistem

Layanan dan Rujukan Terpadu untuk

Perlindungan Sosial dan

Penanggulangan Kemiskinan Tahun 2017.

Peraturan Kabupaten Bandung No.25 Tahun 2017 tentang Pusat Kesejahteraan Sosial Penanganan Kemiskinan

Profil Kabupaten Bandung Tahun 2018.

Ragan, M. 2003. Building better human service systems: Integrating services for income support and related programs. The Institute.

Rauch, Dietmar. 2005. Institutional Fragmentation And Social Service Variations: A Scandinavian Comparison. Doctoral Dissertation, Umeå Universitet.

Robbins SP dan Judge.2002. Perilaku Organisasi. Jakarta:Salemba Empat.

Soelaiman, Holil. 2017. Kesejahteraan Sosial (Konsep dan Praktik). Bandung: STKS Press.

Spiker. 1995. Social Policy: Themes and Approaches. London: Prentice Hall/ Harvester Wheatsheaf.

Suharto, Edi. 2009. Kemiskinan dan Perlindungan Sosial di Indonesia. Bandung: Alfabeta

Sumardi, Pungky. 2017. Presentasi Program Perlindungan Sosial untuk Mengoptimalkan Manfaat: Sinergi Pemerintah Pusat dan Daerah, 19 Oktober 2017. Jakarta.

Undang-Undang Nomor 11 Tahun 2009 tentang Kesejahteraan Sosial
Undang Undang No. 13 Tahun 2011 tentang Penanganan Fakir Miskin

Wahyuningsih. 2017. Millenium Develompent Goals (MDGs) dan Sustainable Development Goals (SDGs) Dalam Kesejahteraan Sosial. Bisma Jurnal Bisnis dan Manajemen, 11, 390-399. 